\title{
Middle East Respiratory Syndrome Coronavirus (MERS-CoV) and Hajj Gatherings
}

\author{
Jaffar A. Al-Tawfiq, Mamunur Rahman Malik, and Ziad A. Memish
}

\section{Contents}

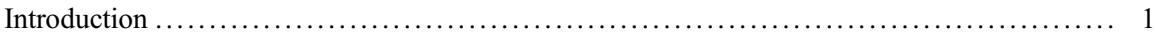

Middle East Respiratory Syndrome Coronavirus (MERS-CoV): The Virus . $\ldots \ldots \ldots \ldots \ldots \ldots \ldots . \ldots \ldots$

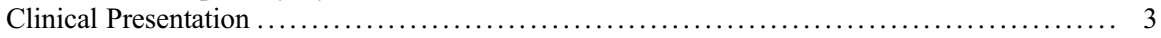

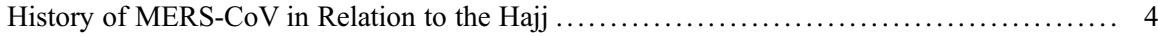

Systematic Screening for MERS-CoV Among Attendees of the Annual Hajj $\ldots \ldots \ldots \ldots \ldots \ldots \ldots$. 5

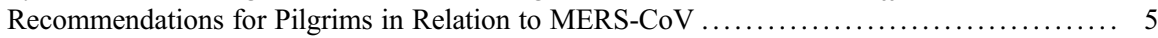

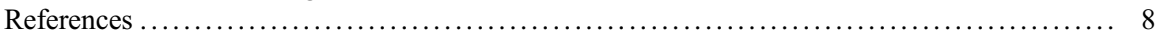

\section{Abstract}

Hajj, the Pilgrimage to the Holy City of Makkah, Saudi Arabia, is one of the largest mass gatherings in the World. Due to the overcrowding, there is a risk of the transmission of infectious diseases from person to person, especially the risk

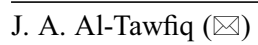

Specialty Internal Medicine and Quality Department, Johns Hopkins Aramco Healthcare, Dhahran, Saudi Arabia

Indiana University School of Medicine, Indianapolis, IN, USA

Johns Hopkins University School of Medicine, Baltimore, MD, USA

e-mail: jaltawfi@yahoo.com

M. R. Malik

Eastern Mediterranean Regional Office of WHO, Cairo, Egypt

e-mail: malikm@who.int

Z. A. Memish

College of Medicine, Alfaisal University, Riyadh, Saudi Arabia

Infectious Diseases Division, Department of Medicine, Prince Mohamed Bin Abdulaziz Hospital ("PMAH"), Ministry of Health, Riyadh, Saudi Arabia

Hubert Department of Global Health, Rollins School of Public Health, Emory University, Atlanta, GA, USA

e-mail: zmemish@yahoo.com 
of respiratory diseases. Since the emergence of Middle East Respiratory Syndrome Coronavirus, there was a significant interest in the risk that this posed to the Hajj. So far, there had been systematic surveillance of the virus among returning Pilgrims and no cases were identified in relation to the Hajj. However, there were two reported MERS-CoV cases related to the mini-Hajj, Umrah, in May 2014. Continued surveillance and vigilance are required to monitor and evaluate the risk in the future.

\section{Keywords}

Hajj $\cdot$ Pilgrimage $\cdot$ Mass gathering $\cdot$ MERS-CoV $\cdot$ Middle east respiratory syndrome coronavirus

\section{Introduction}

Hajj, the pilgrimage to the holy city of Makkah, Saudi Arabia, is one of the largest mass gatherings in the world. Due to the overcrowding, there is a risk of the transmission of infectious diseases from person-to-person, contaminated food or water, respiratory droplet, airborne transmission, and vector-borne transmission (AlTawfiq and Memish 2012a, 2015a; Gautret et al. 2016a). The potential for outbreaks due to person-to-person transmission, food and waterborne disease outbreak, fast and wide geographic spread of diseases, and the introduction of non-endemic diseases are all fearful events during mass gathering. Possible communicable diseases pattern during mass gathering include endemic diseases and imported and exported diseases.

The Hajj draws 3 million Muslims annually, and of these pilgrims, there are 2 million non-Saudis. The majority of $89 \%$ travel by air (Al-Tawfiq and Memish 2012a) from more than 180 countries. The Hajj journey is well described (Memish et al. 2014a). Pilgrims visit the Holy mosque in Makkah, the Plain of Arafat, Muzdaliffah and Mina where pilgrims stay in tents made particularly for pilgrims (Memish et al. 2014a).

The Saudi Ministry of Health pays particular attention to the Hajj with multiple committees. The preventive medicine committee oversees all public health and preventative matters during the Hajj (Memish et al. 2014a; Al-Tawfiq and Memish 2014a). The Kingdom of Saudi Arabia deploys a large number of public health officers to ensure compliance with health requirements. Those healthcare workers ensure compliance with required immunization and administer mandatory prophylactic medications (Memish 2010). There are strong public health teams who diligently monitor the occurrence of communicable diseases using an electronic surveillance (Al-Tawfiq and Memish 2012b). The surveillance particularly monitor influenza, influenza-like illness, meningococcal disease, food poisoning, viral hemorrhagic fevers, yellow fever, cholera, polio, and plague (Memish 2010; Al-Tawfiq and Memish 2012b). With the emergence of Middle East respiratory syndrome coronavirus (MERS-CoV), the disease became also a focus of surveillance especially during the Hajj. Coronaviruses other than MERS-CoV were detected in 
$0.6-0.8 \%$ of the tested population in regard to the Hajj seasons (Al-Tawfiq and Memish 2012b).

\section{Middle East Respiratory Syndrome Coronavirus (MERS-CoV): The Virus}

Human coronaviruses cause acute respiratory illness in humans and include Alphaand Betacoronavirus genera. Betacoronaviruses are divided into four clades (A-D). MERS-CoV is a member of the human betacoronaviruses MERS-CoV and is classified in Clade $\mathrm{C}$ (lineage 3). Similar to the severe acute respiratory syndrome (SARS)-CoV, MERS-CoV is a positive-strand RNA virus. MERS-CoV genome has more than 30,000 nucleotides with 7 predicted open reading frames (ORFs) and 4 structural genes expressing 4 proteins, namely the spike (S) protein, nucleocapsid $(\mathrm{N})$, membrane (M), and envelope (E) proteins (Cotten et al. 2013, 2014). The closest coronavirus to MERS-CoV are Clade $\mathrm{C}$ betacoronaviruses, Tylonycteris bat virus HKU4, Neoromicia zuluensis bat in South Africa, and Pipistrellus bat HKU5 virus (Corman et al. 2014; Ithete et al. 2013; van Boheemen et al. 2012).

\section{Clinical Presentation}

MERS-CoV causes a range of respiratory illness from a mild disease to a severe and life threatening infection. In one study, a three-phase illness was described and included the initial phase of fever and clinical stability probably representing viral replication, followed by an immunologic phase with clinical and radiographic deterioration and subsequent improvement (Al-Tawfiq and Hinedi 2018). In addition, asymptomatic cases had been described. Asymptomatic cases were reported in $12.5 \%$ of 144 confirmed MERS-CoV cases in 2012, and this rate was $25.1 \%$ among 255 confirmed cases (Al-Tawfiq and Gautret 2018). In children, the rate of asymptomatic cases ranged between $41.9 \%$ and $81.8 \%$ (Al-Tawfiq and Gautret 2018; Alfaraj et al. 2018; Al-Tawfiq et al. 2016a; Thabet et al. 2015; Memish et al. 2014b). There are three patterns of MERS-CoV infection: isolated sporadic cases, intra-family clusters, and healthcare-associated infections (Al-Tawfiq and Auwaerter 2018). The clinical presentation of most cases is consistent with respiratory illness and $33 \%$ of patients may have nausea, vomiting, or diarrhea (Al-Tawfiq et al. 2016b). Early symptoms are mild and nonspecific which last several days prior to progressing to severe pneumonia. There are no predictive signs or symptoms to differentiate MERS-CoV from community acquired pneumonia in hospitalized patients (World Health Organization 2015). There is an apparent heterogeneity in transmission. Severe disease is usually seen in primary or index cases, immunocompromised, and people with underlying comorbidities. Mild or asymptomatic disease usually occurs in secondary cases and was initially thought to be only in the young and previously healthy individuals. However, mortalities and severe cases were seen among primary cases and among young individuals (Corman et al. 2014). Although person-to-person transmission is definite, the route of transmission is still 
not clear. The median incubation period was 5.2 days (95\% CI, 1.9-14.7), and the serial interval was 7.6 days (95\% CI, 2.5-23.1) (Assiri et al. 2013b).

There are few studies describing co-infection of MERS-CoV with influenza A, parainfluenza, herpes simplex, and Streptococcus pneumonia and tuberculosis (Alfaraj et al. 2017a, b; World Health Organization 2013).

MERS-CoV infection carries a case fatality rate of 40-60\% (Al-Tawfiq and Memish 2014b; Assiri et al. 2013a, b; Penttinen et al. 2013). Lower case-fatality rates of $20 \%$ were reported in two studies from Saudi Arabia and South Korea. The current study included a larger number of patients spanning a longer duration and the case fatality rate was only $20 \%$ (Al-Tawfiq et al. 2017; Ki 2015). Variable laboratory findings were reported among MERS-CoV patients. Lymphopenia was described in 44-92\% of patients (Assiri et al. 2013a, b; Zaki et al. 2012; Al-Tawfiq et al. 2014a; Hijawi et al. 2013; Guery et al. 2013; Memish et al. 2013a; Arabi et al. 2014). In addition, thrombocytopenia was also described in different studies (Assiri et al. 2013a, b; Arabi et al. 2014; Al-Tawfiq and Memish 2015b).

The main diagnostic test for MERS-CoV is based on real-time reversetranscription polymerase chain reaction (PCR). The samples are either Dacronflocked nasopharyngeal swabs or sputum samples (Assiri et al. 2013b). The PCR test amplifies both the upstream E protein (upE gene) and ORF1a for MERS-CoV. The best samples for the diagnosis of MERS-CoV is lower respiratory samples as these samples have lower $\mathrm{Ct}$ values (higher viral load) and were present later in the course of the disease (Assiri et al. 2013b; Memish et al. 2014c). This also in line with WHO recommendations (World Health Organization 2015).

\section{History of MERS-CoV in Relation to the Hajj}

In the recent years, two novel corona viruses emerged and posed a global threat. These are SARS-CoV in 2003 and MERS-CoV in 2013. It was shown that there were no cases of SARS linked to the Hajj (Al-Tawfiq et al. 2014b). The first two MERSCoV infections occurred weeks before the 2012 annual Muslim Hajj season. The first MERS case was in a Saudi Arabian patient (Zaki et al. 2012) and the second was in a patient from Qatar who was transferred to London (Pebody et al. 2012). The initial 2012 Hajj season started few weeks after the first case of MERS-CoV infection was reported (Memish et al. 2014d). However, there were no reported cases among pilgrims in 2012 (Kandeel et al. 2011; Rashid et al. 2008; Al-Tawfiq et al. 2013; Memish et al. 2013b). Thus, the Saudi Ministry of Health (MoH) utilized the MERS$\mathrm{CoV}$ case definition for monitoring any occurrence of the disease during Hajj for early detection of cases among pilgrims (Al-Tawfiq and Memish 2014a). An enhanced surveillance system was established for the detection of MERS-CoV cases. The disease remains limited to the Middle East with the exception of sporadic travel-associated infections and the large outbreak in South Korea (Sridhar et al. 2015; Kim et al. 2016; Korea Centers for Disease Control and Prevention 2015; Pavli et al. 2014). In one study conducted during September 2012-October 2013, 77 travelers from the Middle East met the possible case definition for MERS and 2 
of them tested positive for MERS (Sridhar et al. 2015). In a small study of 14 retuning pilgrims, all patients were hospitalized for respiratory symptoms and none of them tested positive for MERS-CoV in Marseille France in October 2013 (Gautret et al. 2014). Furthermore, nasopharyngeal swabs were collected from suspected cases and all samples tested negative for MERS-COV (Memish et al. 2014d). Another small study of seven pilgrims was conducted in 2014 in Austria, and none had MERS-CoV (Aberle et al. 2015).

\section{Systematic Screening for MERS-CoV Among Attendees of the Annual Hajj}

Following that, there were systematic screening of pilgrims for MERS-CoV, and none of the studies showed positive cases (Al-Tawfiq et al. 2013; Aberle et al. 2015; Gautret et al. 2013; Barasheed et al. 2014; Baharoon et al. 2009; Memish et al. 2014e, 2015; Annan et al. 2015; Refaey et al. 2016; Atabani et al. 2016; ProMed 2013; Griffiths et al. 2016; Benkouiten et al. 2014; Ma et al. 2017; Al-Abdallat et al. 2017; Koul et al. 2017). Mathematical models estimated the risk of MERS-CoV among pilgrims to be 1-7 cases per Hajj and 3-10 per Umrah per year (Gardner et al. 2014). Early in the history of MERS-CoV, it was estimated that 6.2 pilgrims may develop MERS-CoV symptoms during the Hajj, and 4 pilgrims may become infected and return home before symptoms development (Lessler et al. 2014). Systematic surveillance of returning pilgrims was done in several studies in Egypt, Iran, France, and Ghana as well as studies in Saudi Arabia (Gautret et al. 2013, 2014; Memish et al. 2014e; Annan et al. 2015). The prevalence of non-MERS coronavirus was detected in 1-21\% of pilgrims (Gautret et al. 2013, 2014, 2016a, b; Al-Tawfiq and Memish 2014a; Memish et al. 2012, 2014d, e, 2015; Kandeel et al. 2011; AlTawfiq et al. 2013, 2016c; Aberle et al. 2015; Barasheed et al. 2014; Baharoon et al. 2009; Annan et al. 2015; Refaey et al. 2016; Atabani et al. 2016; ProMed 2013; Griffiths et al. 2016; Benkouiten et al. 2014; Ma et al. 2017; Al-Abdallat et al. 2017; Koul et al. 2017) (Table 1). Despite the extensive surveillance and since the emergence of MERS-CoV, only four cases have been linked to Umrah (Mini-Hajj) (Kraaij-Dirkzwager et al. 2014; Fanoy et al. 2014; ProMed 2014a, b, n.d.). In addition, few studies examined MERS-CoV among symptomatic pilgrims, and none was positive for MERS-CoV (Table 2, Fig. 1) (Memish et al. 2014d; Al-Tawfiq et al. 2013; Aberle et al. 2015).

\section{Recommendations for Pilgrims in Relation to MERS-CoV}

As MERS-CoV emerged in 2012, there were no specific recommendations targeting the newly emerging virus. In October 2012, updated recommendations on health hazards and recommendations for Hajj 2012 were published (Al-Tawfiq and Memish 2012b). The 2012 Hajj season was concluded with no cases of MERS-CoV among pilgrims. More 300 ill pilgrims were tested for MERS-CoV and all were negative 
Table 1 Systematic screening of MERS-CoV among pilgrims

\begin{tabular}{|c|c|c|c|c|c|}
\hline Reference & $\begin{array}{l}\text { Year of the } \\
\text { study }\end{array}$ & \begin{tabular}{|l} 
Study \\
population
\end{tabular} & Method & $\begin{array}{l}\text { Number } \\
\text { screened }\end{array}$ & $\begin{array}{l}\mathrm{N}(\%) \\
\text { positive }\end{array}$ \\
\hline $\begin{array}{l}\text { Gautret et } \\
\text { al. } 2013\end{array}$ & 2012 & French cohort & $\begin{array}{l}\text { Nasopharyngeal } \\
\text { swab }\end{array}$ & 154 & 0 \\
\hline $\begin{array}{l}\text { Gautret et } \\
\text { al. } 2014\end{array}$ & 2013 & $\begin{array}{l}\text { Departing } \\
\text { pilgrims }\end{array}$ & Nasal swabs & 129 & 0 \\
\hline $\begin{array}{l}\text { Barasheed } \\
\text { et al. } 2014\end{array}$ & 2013 & $\begin{array}{l}\text { Pilgrims from } \\
\text { Saudi Arabia, } \\
\text { Australia, and } \\
\text { Qatar }\end{array}$ & Nasal swabs & 1038 & 0 \\
\hline $\begin{array}{l}\text { Refaey et } \\
\text { al. } 2016\end{array}$ & $2012-2015$ & Egyptian & $\begin{array}{l}\text { Nasopharyngeal } \\
\text { and } \\
\text { oropharyngeal } \\
\text { swabs }\end{array}$ & 484 & 0 \\
\hline $\begin{array}{l}\text { Annan et } \\
\text { al. } 2015\end{array}$ & 2013 & $\begin{array}{l}\text { Adult African } \\
\text { Hajj pilgrims } \\
\text { returning to } \\
\text { Ghana, West } \\
\text { Africa }\end{array}$ & $\begin{array}{l}\text { Nasopharyngeal } \\
\text { swab }\end{array}$ & 839 & 0 \\
\hline $\begin{array}{l}\text { Memish et } \\
\text { al. } 2015\end{array}$ & 2013 & $\begin{array}{l}\text { Departing } \\
\text { pilgrims, } \\
\text { paired, and } \\
\text { non-paired } \\
\text { cohort }\end{array}$ & Nasal swabs & $\begin{array}{l}692 \text { (paired } \\
\text { cohort), } 514 \\
\text { (non-paired } \\
\text { arriving } \\
\text { cohorts); and } \\
470 \text { (non-paired } \\
\text { departing } \\
\text { cohort) }\end{array}$ & 0 \\
\hline $\begin{array}{l}\text { Gautret et } \\
\text { al. } 2014 \text {; } \\
\text { Benkouiten } \\
\text { et al. } 2014\end{array}$ & 2013 & $\begin{array}{l}\text { French } \\
\text { pilgrims }\end{array}$ & $\begin{array}{l}\text { Nasal and throat } \\
\text { swab }\end{array}$ & 129 & 0 \\
\hline $\begin{array}{l}\text { Memish et } \\
\text { al. } 2014 \mathrm{e}\end{array}$ & 2013 & $\begin{array}{l}\text { Multiple } \\
\text { nationalities }\end{array}$ & $\begin{array}{l}\text { Nasopharyngeal } \\
\text { swab }\end{array}$ & 3210 pre-Hajj & 0 \\
\hline $\begin{array}{l}\text { Memish et } \\
\text { al. } 2014 \mathrm{e}\end{array}$ & 2013 & $\begin{array}{l}\text { Multiple } \\
\text { nationalities }\end{array}$ & $\begin{array}{l}\text { Nasopharyngeal } \\
\text { swab }\end{array}$ & 2025 post-Hajj & 0 \\
\hline $\begin{array}{l}\text { Atabani et } \\
\text { al. } 2016\end{array}$ & 2013-2015 & $\begin{array}{l}\text { Symptomatic } \\
\text { British } \\
\text { pilgrims }\end{array}$ & $\begin{array}{l}\text { Upper and lower } \\
\text { respiratory tract }\end{array}$ & 202 & 0 \\
\hline $\begin{array}{l}\text { Griffiths et } \\
\text { al. } 2016\end{array}$ & $2013-2015$ & $\begin{array}{l}\text { Ill French } \\
\text { travelers }\end{array}$ & Not indicated & 33 & 0 \\
\hline $\begin{array}{l}\text { Ma et al. } \\
2017\end{array}$ & 2013-2015 & Chinese & $\begin{array}{l}\text { Lower } \\
\text { respiratory tract } \\
\text { sputum, washes, } \\
\text { and upper } \\
\text { respiratory tract } \\
\text { oropharyngeal } \\
\text { swab }\end{array}$ & 847 & 0 \\
\hline
\end{tabular}


Table 1 (continued)

\begin{tabular}{l|l|l|l|l|l}
\hline Reference & $\begin{array}{l}\text { Year of the } \\
\text { study }\end{array}$ & $\begin{array}{l}\text { Study } \\
\text { population }\end{array}$ & Method & $\begin{array}{l}\text { Number } \\
\text { screened }\end{array}$ & $\begin{array}{l}\text { N (\%) } \\
\text { positive }\end{array}$ \\
\hline $\begin{array}{l}\text { Al-Abdallat } \\
\text { et al. 2017 }\end{array}$ & 2015 & Jordanian & $\begin{array}{l}\text { Nasopharyngeal } \\
\text { and } \\
\text { oropharyngeal }\end{array}$ & 125 & 0 \\
\hline $\begin{array}{l}\text { Koul et al. } \\
2017\end{array}$ & $2014-2015$ & $\begin{array}{l}\text { Kashmir, } \\
\text { north India }\end{array}$ & $\begin{array}{l}\text { Nasopharyngeal } \\
\text { and throat swabs }\end{array}$ & 300 & 0 \\
\hline
\end{tabular}

Table 2 Screening of symptomatic pilgrims for MERS-CoV

\begin{tabular}{l|l|l|l|l|l}
\hline Reference & $\begin{array}{l}\text { Year of } \\
\text { the } \\
\text { study }\end{array}$ & Study population & Method & $\begin{array}{l}\text { Number } \\
\text { screened }\end{array}$ & $\begin{array}{l}\text { N (\%) } \\
\text { positive }\end{array}$ \\
\hline $\begin{array}{l}\text { Al-Tawfiq } \\
\text { et al. 2013 }\end{array}$ & 2012 & $\begin{array}{l}\text { Symptomatic } \\
\text { French }\end{array}$ & Nasopharyngeal swab & 300 & 0 \\
\hline $\begin{array}{l}\text { Memish et } \\
\text { al. 2014d }\end{array}$ & 2013 & $\begin{array}{l}\text { Admitted pilgrims } \\
\text { with pneumonia }\end{array}$ & Sputum & 38 & 0 \\
\hline $\begin{array}{l}\text { Aberle et } \\
\text { al. 2015 }\end{array}$ & 2014 & $\begin{array}{l}\text { Symptomatic } \\
\text { pilgrims returning } \\
\text { to Austria }\end{array}$ & $\begin{array}{l}\text { Sputum, throat swab, } \\
\text { or bronchoalveolar } \\
\text { lavage }\end{array}$ & 7 & 0 \\
\hline
\end{tabular}

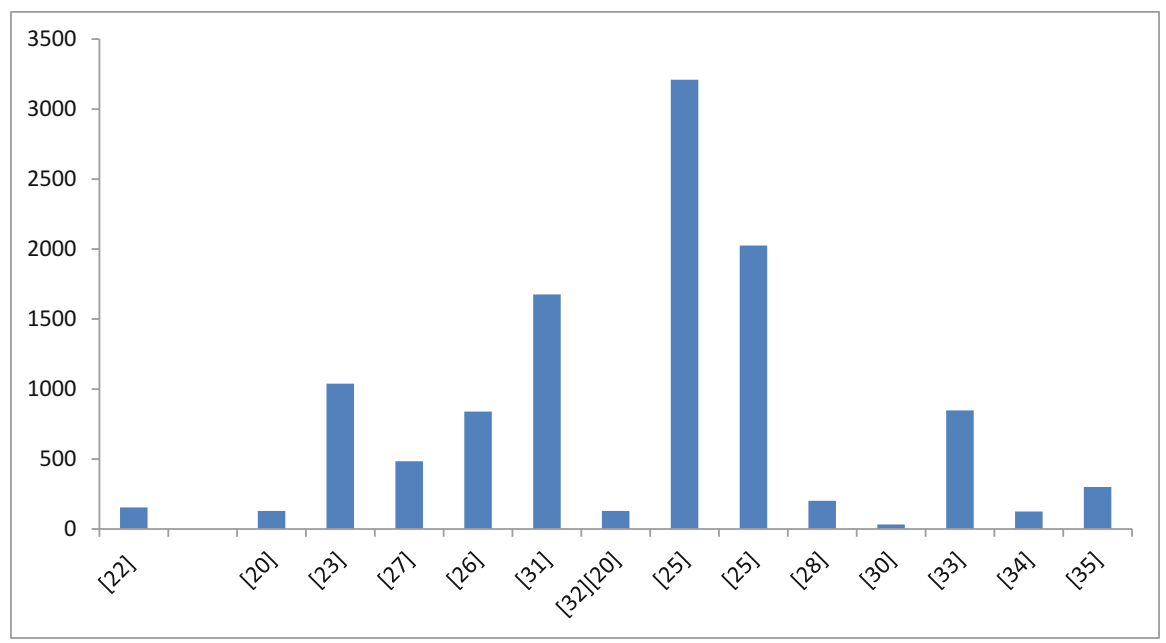

Fig. 1 Histogram shows the number of systematic screened pilgrims for MERS-CoV and none of them tested positive

(Al-Tawfiq et al. 2013). There are no special recommendations for pilgrims in regard to MERS-CoV infection. Pilgrims are advised to practice proper hand hygiene, protective behaviors, and cough etiquette. It is also recommended that pilgrims avoid contacts with camels (Al-Tawfiq and Memish 2012b). In addition, in 2015, 
Saudi Arabia banned the sacrifice of camels for Hajj and discouraged visits by pilgrims to camel barns during Hajj activities (Gautret et al. 2016b).

\section{Conclusion}

MERS-CoV infection remains very rare among pilgrims. There were extensive surveillance of pilgrims for the existence of MERS-CoV, but all were negative. However, two cases were detected among returning travelers after performing Umrah (mini-Hajj). Continued surveillance and vigilance are required to further enhance public awareness and inform evidence-based practices.

\section{References}

Aberle JH, Popow-Kraupp T, Kreidl P, Laferl H, Heinz FX, Aberle SW (2015) Influenza A and B viruses but not MERS-CoV in Hajj pilgrims, Austria, 2014. Emerg Infect Dis 21:726-727. https://doi.org/10.3201/eid2104.141745

Alfaraj SH, Al-Tawfiq JA, Alzahrani NA, Altwaijri TA, Memish ZA (2017a) The impact of coinfection of influenza A virus on the severity of Middle East respiratory syndrome coronavirus. $\mathrm{J}$ Infect 74:521-523. https://doi.org/10.1016/j.jinf.2017.02.001

Alfaraj SH, Al-Tawfiq JA, Altuwaijri TA, Memish ZA (2017b) Middle East respiratory syndrome coronavirus and pulmonary tuberculosis coinfection: implications for infection control. Intervirology 60:53-55. https://doi.org/10.1159/000477908

Alfaraj SH, Al-Tawfiq JA, Altuwaijri TA, Memish ZA (2018) Middle East respiratory syndrome coronavirus in pediatrics: a report of seven cases from Saudi Arabia. Front Med. https://doi.org/ 10.1007/s11684-017-0603-y

Al-Abdallat MM, Rha B, Alqasrawi S, Payne DC, Iblan I, Binder AM et al (2017) Acute respiratory infections among returning Hajj pilgrims - Jordan, 2014. J Clin Virol 89:34-37. https:/doi.org/ 10.1016/j.jcv.2017.01.010

Al-Tawfiq JA, Auwaerter PG (2018) Healthcare-associated infections: the hallmark of the Middle East respiratory syndrome coronavirus (MERS-CoV) with review of the literature. J Hosp Infect. https://doi.org/10.1016/j.jhin.2018.05.021

Al-Tawfiq JA, Gautret P (2018) Asymptomatic Middle East respiratory syndrome coronavirus (MERS-CoV) infection: extent and implications for infection control: a systematic review. Travel Med Infect Dis. https://doi.org/10.1016/j.tmaid.2018.12.003

Al-Tawfiq JA, Hinedi K (2018) The calm before the storm: clinical observations of Middle East respiratory syndrome (MERS) patients. J Chemother. https://doi.org/10.1080/1120009X.2018.1 429236

Al-Tawfiq JA, Memish ZA (2012a) Mass gatherings and infectious diseases: prevention, detection, and control. Infect Dis Clin North Am 26:725-737. https://doi.org/10.1016/j.idc.2012.05.005

Al-Tawfiq JA, Memish ZA (2012b) The Hajj: updated health hazards and current recommendations for 2012. Euro Surveill 17:20295

Al-Tawfiq JA, Memish ZA (2014a) Mass gathering medicine: 2014 Hajj and Umra preparation as a leading example. Int J Infect Dis 27:26-31

Al-Tawfiq JA, Memish ZA (2014b) Middle East respiratory syndrome coronavirus: epidemiology and disease control measures. Infect Drug Resist 7:281-287. https://doi.org/10.2147/IDR.S5 1283

Al-Tawfiq JA, Memish ZA (2015a) Potential risk for drug resistance globalization at the Hajj. Clin Microbiol Infect 21:109-114. https://doi.org/10.1016/j.cmi.2014.11.013 
Al-Tawfiq JAA, Memish ZAA (2015b) Managing MERS-CoV in the healthcare setting. Hosp Pract 43:158-163. https://doi.org/10.1080/21548331.2015.1074029

Al-Tawfiq JA, Smallwood CAH, Arbuthnott KG, Malik MSK, Barbeschi M, Memish ZA (2013) Emerging respiratory and novel coronavirus 2012 infections and mass gatherings. East Mediterr Health J 19(Suppl 1):S48-S54

Al-Tawfiq JA, Hinedi K, Ghandour J, Khairalla H, Musleh S, Ujayli A et al (2014a) Middle East respiratory syndrome-coronavirus (MERS-CoV): a case-control study of hospitalized patients. Clin Infect Dis 59:160-165. https://doi.org/10.1093/cid/ciu226

Al-Tawfiq JA, Zumla A, Memish ZA (2014b) Travel implications of emerging coronaviruses: SARS and MERS-CoV. Travel Med Infect Dis 12:422-428. https://doi.org/10.1016/j.tmaid. 2014.06.007

Al-Tawfiq JA, Kattan RF, Memish ZA (2016a) Middle East respiratory syndrome coronavirus disease is rare in children: an update from Saudi Arabia. World J Clin Pediatr 5:391-396. https:// doi.org/10.5409/wjcp.v5.i4.391

Al-Tawfiq JA, Omrani AS, Memish ZA (2016b) Middle East respiratory syndrome coronavirus: current situation and travel-associated concerns. Front Med 10:111. https://doi.org/10.1007/ s11684-016-0446-y

Al-Tawfiq JA, Gautret P, Benkouiten S, Memish ZA (2016c) Mass gatherings and the spread of respiratory infections. Lessons from the Hajj. Ann Am Thorac Soc 13:759-765. https://doi.org/ 10.1513/AnnalsATS.201511-772FR

Al-Tawfiq JA, Alfaraj SH, Altuwaijri TA, Memish ZA (2017) A cohort-study of patients suspected for MERS-CoV in a referral hospital in Saudi Arabia. J Infect 75:378-379. https://doi.org/ 10.1016/j.jinf.2017.06.002

Annan A, Owusu M, Marfo KS, Larbi R, Sarpong FN, Adu-Sarkodie Y et al (2015) High prevalence of common respiratory viruses and no evidence of Middle East respiratory syndrome coronavirus in Hajj pilgrims returning to Ghana, 2013. Trop Med Int Health 20:807-812. https:// doi.org/10.1111/tmi.12482

Arabi YM, Arifi AA, Balkhy HH, Najm H, Aldawood AS, Ghabashi A et al (2014) Clinical course and outcomes of critically ill patients with Middle East respiratory syndrome coronavirus infection. Ann Intern Med 160:389-397. https://doi.org/10.7326/M13-2486

Assiri A, McGeer A, Perl TM, Price CS, Al Rabeeah AA, Cummings DAT et al (2013a) Hospital outbreak of Middle East respiratory syndrome coronavirus. N Engl J Med 369:407-416. https:// doi.org/10.1056/NEJMoa1306742

Assiri A, Al-Tawfiq JA, Al-Rabeeah AA, Al-Rabiah FA, Al-Hajjar S, Al-Barrak A et al (2013b) Epidemiological, demographic, and clinical characteristics of 47 cases of Middle East respiratory syndrome coronavirus disease from Saudi Arabia: a descriptive study. Lancet Infect Dis 13:752-761. https://doi.org/10.1016/S1473-3099(13)70204-4

Atabani SF, Wilson S, Overton-Lewis C, Workman J, Kidd IM, Petersen E et al (2016) Active screening and surveillance in the United Kingdom for Middle East respiratory syndrome coronavirus in returning travellers and pilgrims from the Middle East: a prospective descriptive study for the period 2013-2015. Int J Infect Dis 47:10-14. https://doi.org/10.1016/j.ijid. 2016.04.016

Baharoon S, Al-Jahdali H, Al Hashmi J, Memish ZA, Ahmed QA (2009) Severe sepsis and septic shock at the Hajj: etiologies and outcomes. Travel Med Infect Dis 7:247-252. https://doi.org/ 10.1016/j.tmaid.2008.09.002

Barasheed O, Rashid H, Alfelali M, Tashani M, Azeem M, Bokhary H et al (2014) Viral respiratory infections among Hajj pilgrims in 2013. Virol Sin 29:364-371. https://doi.org/10.1007/s12250014-3507-x

Benkouiten S, Charrel R, Belhouchat K, Drali T, Nougairede A, Salez N et al (2014) Respiratory viruses and bacteria among pilgrims during the 2013 Hajj. Emerg Infect Dis 20:1821-1827. https://doi.org/10.3201/eid2011.140600 
Corman VM, Ithete NL, Richards LR, Schoeman MC, Preiser W, Drosten C et al (2014) Rooting the phylogenetic tree of MERS-coronavirus by characterization of a conspecific virus from an African Bat. J Virol 88:11297-11303. https://doi.org/10.1128/JVI.01498-14

Cotten M, Watson SJ, Kellam P, Al-Rabeeah AA, Makhdoom HQ, Assiri A et al (2013) Transmission and evolution of the Middle East respiratory syndrome coronavirus in Saudi Arabia: a descriptive genomic study. Lancet 382:1993-2002. https://doi.org/10.1016/S01406736(13)61887-5

Cotten M, Watson SJ, Zumla AI, Makhdoom HQ, Palser AL, Ong SH et al (2014) Spread, circulation, and evolution of the Middle East respiratory syndrome coronavirus. MBio 5: pii: e01062-13. https://doi.org/10.1128/mBio.01062-13

Fanoy EB, van der Sande MA, Kraaij-Dirkzwager M, Dirksen K, Jonges M, van der Hoek W et al (2014) Travel-related MERS-CoV cases: an assessment of exposures and risk factors in a group of Dutch travellers returning from the Kingdom of Saudi Arabia, May 2014. Emerg Themes Epidemiol 11:16. https://doi.org/10.1186/1742-7622-11-16

Gardner LM, Rey D, Heywood AE, Toms R, Wood J, Travis Waller S et al (2014) A scenario-based evaluation of the Middle East respiratory syndrome coronavirus and the Hajj. Risk Anal 34:1391-1400. https://doi.org/10.1111/risa.12253

Gautret P, Charrel R, Belhouchat K, Drali T, Benkouiten S, Nougairede A et al (2013) Lack of nasal carriage of novel corona virus (HCoV-EMC) in French Hajj pilgrims returning from the Hajj 2012, despite a high rate of respiratory symptoms. Clin Microbiol Infect 19:E315-E317. https:// doi.org/10.1111/1469-0691.12174

Gautret P, Charrel R, Benkouiten S, Belhouchat K, Nougairede A, Drali T et al (2014) Lack of MERS coronavirus but prevalence of influenza virus in French pilgrims after 2013 Hajj. Emerg Infect Dis 20:728-730. https://doi.org/10.3201/eid2004.131708

Gautret P, Benkouiten S, Al-Tawfiq JA, Memish ZA (2016a) Hajj-associated viral respiratory infections: a systematic review. Travel Med Infect Dis 14:92-109. https://doi.org/10.1016/j. tmaid.2015.12.008

Gautret P, Benkouiten S, Al-Tawfiq JA, Memish ZA (2016b) The spectrum of respiratory pathogens among returning Hajj pilgrims: myths and reality. Int J Infect Dis 47:83-85. https://doi.org/ 10.1016/j.ijid.2016.01.013

Griffiths K, Charrel R, Lagier J-C, Nougairede A, Simon F, Parola P et al (2016) Infections in symptomatic travelers returning from the Arabian peninsula to France: a retrospective crosssectional study. Travel Med Infect Dis 14:414-416. https://doi.org/10.1016/j.tmaid.2016.05.002

Guery B, Poissy J, el Mansouf L, Séjourné C, Ettahar N, Lemaire X et al (2013) Clinical features and viral diagnosis of two cases of infection with Middle East respiratory syndrome coronavirus: a report of nosocomial transmission. Lancet 381:2265-2272. https://doi.org/10.1016/ S0140-6736(13)60982-4

Hijawi B, Abdallat M, Sayaydeh A, Alqasrawi S, Haddadin A, Jaarour N et al (2013) Novel coronavirus infections in Jordan, April 2012: epidemiological findings from a retrospective investigation. East Mediterr Health J 19(Suppl 1):S12-S18

Ithete NL, Stoffberg S, Corman VM, Cottontail VM, Richards LR, Schoeman MC et al (2013) Close relative of human Middle East respiratory syndrome coronavirus in bat, South Africa. Emerg Infect Dis 19:1697-1699. https://doi.org/10.3201/eid1910.130946

Kandeel A, Deming M, Elkreem EA, El-Refay S, Afifi S, Abukela M et al (2011) Pandemic (H1N1) 2009 and Hajj Pilgrims who received predeparture vaccination, Egypt. Emerg Infect Dis 17:1266-1268. https://doi.org/10.3201/eid1707.101484

Ki M (2015) 2015 MERS outbreak in Korea: hospital-to-hospital transmission. Epidemiol Health 37:e2015033. https://doi.org/10.4178/epih/e2015033

Kim Y, Lee S, Chu C, Choe S, Hong S, Shin Y (2016) The characteristics of Middle Eastern respiratory syndrome coronavirus transmission dynamics in South Korea. Osong Public Health Res Perspect 7:49-55. https://doi.org/10.1016/j.phrp.2016.01.001 
Korea Centers for Disease Control and Prevention (2015) Middle East respiratory syndrome coronavirus outbreak in the Republic of Korea, 2015. Osong Public Health Res Perspect 6:269-278. https://doi.org/10.1016/j.phrp.2015.08.006

Koul PA, Mir H, Saha S, Chadha MS, Potdar V, Widdowson M-A et al (2017) Influenza not MERS $\mathrm{CoV}$ among returning Hajj and Umrah pilgrims with respiratory illness, Kashmir, north India, 2014-15. Travel Med Infect Dis 15:45-47. https://doi.org/10.1016/j.tmaid.2016.12.002

Kraaij-Dirkzwager M, Timen A, Dirksen K, Gelinck L, Leyten E, Groeneveld P et al (2014) Middle East respiratory syndrome coronavirus (MERS-CoV) infections in two returning travellers in the Netherlands, May 2014. Euro Surveill 19:pii: 20817

Lessler J, Rodriguez-Barraquer I, Cummings DA, Garske T, Van Kerkhove M, Mills H et al (2014) Estimating potential incidence of MERS-CoV associated with Hajj pilgrims to Saudi Arabia, 2014. PLoS Curr 6:1-18. https://doi.org/10.1371/currents.outbreaks.c5c9c9abd636164a9b6fd 4dbda974369

Ma X, Liu F, Liu L, Zhang L, Lu M, Abudukadeer A et al (2017) No MERS-CoV but positive influenza viruses in returning Hajj pilgrims, China, 2013-2015. BMC Infect Dis 17:715. https:// doi.org/10.1186/s12879-017-2791-0

Memish ZA (2010) The Hajj: communicable and non-communicable health hazards and current guidance for pilgrims. Euro Surveill 15:19671

Memish ZA, Assiri AM, Hussain R, Alomar I, Stephens G (2012) Detection of respiratory viruses among pilgrims in Saudi Arabia during the time of a declared influenza $\mathrm{A}(\mathrm{H} 1 \mathrm{~N} 1)$ pandemic. J Travel Med 19:15-21. https://doi.org/10.1111/j.1708-8305.2011.00575.x

Memish ZA, Zumla AI, Al-Hakeem RF, Al-Rabeeah AA, Stephens GM (2013a) Family cluster of Middle East respiratory syndrome coronavirus infections. N Engl J Med 368:2487-2494. https://doi.org/10.1056/NEJMoa1303729

Memish ZA, Zumla A, Al-Tawfiq JA (2013b) How great is the risk of Middle East respiratory syndrome coronavirus to the global population? Expert Rev Anti Infect Ther 11:979-981. https://doi.org/10.1586/14787210.2013.836965

Memish ZA, Zumla A, Alhakeem RF, Assiri A, Turkestani A, Al Harby KD et al (2014a) Hajj: infectious disease surveillance and control. Lancet 383:2073-2082. https://doi.org/10.1016/ S0140-6736(14)60381-0

Memish ZAZA, Al-Tawfiq JAJA, Assiri A, Alrabiah FAFA, Al Hajjar S, Albarrak A et al (2014b) Middle East respiratory syndrome coronavirus disease in children. Pediatr Infect Dis J 33: 904-906. https://doi.org/10.1097/INF.0000000000000325

Memish ZAZA, Al-Tawfiq JAJA, Makhdoom HQHQ, Assiri A, Alhakeem RFRF, Albarrak A et al (2014c) Respiratory tract samples, viral load, and genome fraction yield in patients with Middle East respiratory syndrome. J Infect Dis 210:1590-1594. https://doi.org/10.1093/infdis/jiu292

Memish ZA, Almasri M, Turkestani A, Al-Shangiti AM, Yezli S (2014d) Etiology of severe community-acquired pneumonia during the 2013 Hajj-part of the MERS-CoV surveillance program. Int J Infect Dis 25:186-190. https://doi.org/10.1016/j.ijid.2014.06.003

Memish ZA, Assiri A, Almasri M, Alhakeem RF, Turkestani A, Al Rabeeah AA et al (2014e) Prevalence of MERS-CoV nasal carriage and compliance with the Saudi health recommendations among pilgrims attending the 2013 Hajj. J Infect Dis 210:1067-1072. https://doi.org/ 10.1093/infdis/jiu150

Memish ZA, Assiri A, Turkestani A, Yezli S, Al Masri M, Charrel R et al (2015) Mass gathering and globalization of respiratory pathogens during the 2013 Hajj. Clin Microbiol Infect 21:571. e1-571.e8. https://doi.org/10.1016/j.cmi.2015.02.008

Pavli A, Tsiodras S, Maltezou HC (2014) Middle East respiratory syndrome coronavirus (MERS-CoV): prevention in travelers. Travel Med Infect Dis 12:602-608. https://doi.org/ 10.1016/j.tmaid.2014.10.006

Pebody RG, Chand MA, Thomas HL, Green HK, Boddington NL, Carvalho C et al (2012) The United Kingdom public health response to an imported laboratory confirmed case of a novel coronavirus in September 2012. Euro Surveill 17:20292

Penttinen PM, Kaasik-Aaslav K, Friaux A, Donachie A, Sudre B, Amato-Gauci AJ et al (2013) Taking stock of the first 133 MERS coronavirus cases globally-is the epidemic changing? Eurosurveillance 18(39): pii: 20596 
ProMed (2013) Novel coronavirus - Eastern Mediterranean (03): Saudi comment, 12 February 2013. http://promedmail.org/post/20130326.1603038

ProMed (2014a) MERS-CoV - Eastern Mediterranean (73): Saudi Arabia, Algeria, Jordan, WHO, RFI. http://www.promedmail.org/post/20140601.2512766. Accessed 11 Nov 2016

ProMed (2014b) MERS-CoV (01): Bangladesh, KSA, Algeria, UAE, Iran, WHO, RFI Archive Number: 20140616.2541707. http://www.promedmail.org/post/20140616.2541707

ProMed (n.d.) MERS-CoV - Eastern Mediterranean (80): S Arabia, Iran, Algeria, Tunisia. http:// promedmail.chip.org/pipermail/promed/2014-June/004423.html

Rashid H, Shafi S, Haworth E, El Bashir H, Memish ZA, Sudhanva M et al (2008) Viral respiratory infections at the Hajj: comparison between UK and Saudi pilgrims. Clin Microbiol Infect 14:569-574. https://doi.org/10.1111/j.1469-0691.2008.01987.x

Refaey S, Amin MM, Roguski K, Azziz-Baumgartner E, Uyeki TM, Labib M et al (2016) Cross-sectional survey and surveillance for influenza viruses and MERS-CoV among Egyptian pilgrims returning from Hajj during 2012-2015. Influenza Other Respir Viruses. https://doi.org/ 10.1111/irv.12429

Sridhar S, Brouqui P, Parola P, Gautret P (2015) Imported cases of Middle East respiratory syndrome: an update. Travel Med Infect Dis 13:106-109. https://doi.org/10.1016/j.tmaid. 2014.11.006

Thabet F, Chehab M, Bafaqih H, Al Mohaimeed S (2015) Middle East respiratory syndrome coronavirus in children. Saudi Med J 36:484-486. https://doi.org/10.15537/smj.2015.4.10243

van Boheemen S, de Graaf M, Lauber C, Bestebroer TM, Raj VS, Zaki AM et al (2012) Genomic characterization of a newly discovered coronavirus associated with acute respiratory distress syndrome in humans. MBio 3:pii: e0473-12. https://doi.org/10.1128/mBio.00473-12

World Health Organization (2013) WHO guidelines for investigation of cases of human infection with Middle East respiratory syndrome coronavirus (MERS-CoV). http://www.who.int/ csr/disease/coronavirus_infections/MERS_CoV_investigation_guideline_Jul13.pdf. Accessed 17 Jan 2017

World Health Organization (2015) Laboratory testing for Middle East respiratory syndrome coronavirus (MERS-CoV). http://apps.who.int/iris/bitstream/10665/176982/1/WHO_MERS LAB_15.1_eng.pdf?ua $=1$. Accessed 20 Dec 2016

Zaki AM, van Boheemen S, Bestebroer TM, Osterhaus ADME, Fouchier RAM (2012) Isolation of a novel coronavirus from a man with pneumonia in Saudi Arabia. N Engl J Med 367: 1814-1820. https://doi.org/10.1056/NEJMoa1211721 